\title{
Érdemes-e csatlakozniuk az európai bankunióhoz az euróövezeten kívüli tagállamoknak?
}

Az euróövezet tagállamai automatikusan tagjai az európai bankuniónak, míg az euróövezeten kívüli tagállamoknak lehetőségük van az önkéntes csatlakozásra már az euróövezetbe való belépés előtt. Ezt az Európai Unió szabályai lehetővé teszik, de nem bátorítják, hiszen a nem euróövezeti tagállamokra számos hátrányos megkülönböztetés vonatkozik. Ugyanakkor a csatlakozás több fontos elönnyel is jár az ezt választó országok számára. Vagyis a bankunióhoz való korai csatlakozásról szóló döntés többdimenziós kérdés, mérlegelendő előnyökkel és hátrányokkal. A cikk a hat nem euróövezeti kelet-közép-európai tagállam (Bulgária, Cseh Köztársaság, Horvátország, Magyarország, Lengyelország és Románia) szempontjából elemzi a bankunió felépítését, valamint bankrendszereik sajátosságait és bankunióhoz való viszonyukat, arra keresve a választ, hogy érdekükben áll-e a bankunióhoz való korai csatlakozás. A téma azért is különösen érdekes, mert a szakirodalom is ellentmondásos, és az érintett országok szakpolitikai álláspontja is igen megosztott a kérdéssel kapcsolatban.

Journal of Economic Literature (JEL) kód: F02, F15, F30, G20, G21.

A 2008-tól kibontakozó globális pénzügyi válság részeként az európai országok és bankrendszereik válsága egymást erősítették. Bizonyos tagállamok esetében (például Írország vagy Spanyolország) a bankok megmentésére fordított hatalmas pénzösszegek növelték a szuverén kockázatokat, ami tovább csökkentette a banki portfóliókban levő állampapírok értékét, és további bankmentő csomagokat tett szükségessé, míg például Görögország esetében a szuverén válság vezetett a bankrendszer megrendüléséhez, ami tovább erősítette az ország költségvetési problémáit. Az európai bankunió létrehozásának elsődleges célja, hogy megtörje ezt a bűvös kört, erősítse az Európai Unió pénzügyi stabilitását és bankrendszerének ellenálló képességét. A bankunió létrehozása nagyon fontos és jelentős lépés az európai integráció további erősítésének folyamatában, de nem az összes EU-tagállam, hanem csak az euróövezet tagállamai számára, amelyek automatikusan tagjai a bankuniónak, valamint azon tagállamok

* A szerző köszönettel tartozik Móra Máriának és Neményi Juditnak a cikk korábbi változatához füzött hasznos észrevételeiért.

Mérő Katalin a Budapesti Gazdasági Egyetem docense (e-mail: mero.katalin@uni-bge.hu).

DOI: http://dx.doi.org/10.18414/KSZ.2019.5.497 
számára, amelyek ugyan nem tagjai az euróövezetnek, de az önkéntes csatlakozást választják, úgynevezett szoros együttműködés formájában. Vagyis jelenlegi formájában a bankunió a kétsebességes Európát erősíti, hiszen számottevően mélyíti a tagállamai közötti pénzügyi integrációt, miközben jelentősen tovább növeli a tagjai és a kívül maradók közötti különbségeket (Howarth-Quaglia [2013], Schimmelfenning [2016]). Ezért a gyors és önkéntes csatlakozás kérdése kiemelkedően fontos mind az európai integráció, mind az euróövezeten kívüli országok szempontjából. Ebben a cikkben a kérdést a hat nem euróövezeti közép-kelet-európai ország (KKE6), vagyis Bulgária, a Cseh Köztársaság, Horvátország, Lengyelország, Magyarország és Románia szemszögéböl elemezzük.

A bankunió létrehozására irányuló európai ütemterv (EB [2012]) szerint a bankunió három pilléren nyugszik: az egységes bankfelügyeleti rendszeren (Single Supervisory Mechanism, SSM), az egységes válságkezelési (szanálási) rendszeren (Single Resolution Mechanism, SRM), valamint az európai betétbiztosítási rendszeren (European Deposit Insurance Scheme, EDIS). A három pillér közül csak az első kettőt hozták létre, a betétbiztosítási rendszer kialakítása még politikai viták tárgya. Elsőként az egységes bankfelügyeleti rendszer kezdte meg a működését 2014 novemberében. Ennek keretében a bankfelügyeletet szupranacionális szintre delegálták a tagállamok. Az Európai Központi Bank lett a bankfelügyeleti hatóság, amely közvetlenül felügyeli az EU legjelentősebb bankjait, és közvetetten, a nemzeti felügyeleti hatóságokon keresztül a többit. A bankok jelentőségének megállapítása méretük, az európai és a nemzeti piacok szempontjából való fontosságuk, valamint tevékenységük nemzetközi jellege alapján történik. Emellett jelentősnek minősítik - és így az Európai Központi Bank (EKB) közvetlenül felügyeli - a bankunió minden tagállamának három legnagyobb bankját, illetve azokat a bankokat is, amelyek támogatást kértek vagy kaptak az európai pénzügyi stabilitási eszközből (European Financial Stability Facility, EFSF) vagy az európai stabilitási mechanizmustól (European Stability Mechanism, ESM). Jelenleg - a 2019. márciusi állapot szerint - az EKB 117 bankot minősít jelentősnek és felügyel közvetlenül.

A bankunió második pillére, az egységes válságkezelési rendszer azoknak a bankoknak a válságkezelésére vonatkozik, amelyeket az EKB felügyel. Közvetlen hatáskörébe tartoznak azok a bankok, amelyeket az EKB közvetlenül felügyel, valamint a határon átnyúló tevékenységet végző bankcsoportok. Ennek megfelelően a válságkezelési rendszer nagyobb intézményi kört fed le (jelenleg 142 bankot és határon átnyúló tevékenységü bankcsoportot), mint a közvetlen bankfelügyeleti rendszer. Bankcsőd esetén, amennyiben az erre vonatkozó, előre definiált szigorú feltételek fennállnak, sor kerülhet a bank szanálására. A válságkezelési rendszer keretében a szanálást a brüsszeli székhelyü, erre a célra létrehozott egységes szanálási hatóság (Single Resolution Board, SRB) végzi. Ennek az a célja, hogy a szanálás olyan rendezett folyamat legyen, amely a lehetö legkisebb terhet rakja az adófizetőkre, és a lehető legkevésbé káros a reálgazdaságra. Az SRB 2015. január 1-jén kezdte meg a müködését előkészítő tevékenységét, és 2016. január 1-jétől működik teljes felhatalmazással. Az SRM pénzügyi alapjának, az Egységes Szanálási Alapnak (Single Resolution Fund, SRF) a kezelését szintén az SRB végzi. A szanálási 
alapot a bankunió bankjai finanszírozzák ${ }^{1}$ oly módon, hogy 2023-ig - nyolc éven keresztül - fokozatosan töltik fel.

Ezeken a pilléreken kívül a bankunió alapját képezi az egységes szabálykönyv is. A bankszabályozás és -felügyelet egységes szabálykönyvének kialakítását és folyamatos fejlesztését az Európai Bankhatóság (EBH) végzi. A kialakított prudenciális szabályokat és felügyeleti eljárásrendeket az EU kötelező érvényű technikai standardok formájában jeleníti meg. A bankunió már működő két pillére és az egységes szabálykönyv között az a fö különbség, hogy míg az elöbbi csak a bankunió tagállamaira vonatkozik, addig az utóbbi minden uniós tagállamra.

Az euróövezeten kívüli EU-tagállamoknak lehetőségük van arra, hogy még az euróövezethez való csatlakozás elött önkéntesen kérjék felvételüket a bankunióba, úgynevezett szoros együttmüködésre lépve a bankunióval. A szoros együttmüködés kialakítása azonban nem automatikusan történik, hanem az EKB döntése alapján. Az EKB ekkor az egységes bankfelügyeleti rendszer létrehozását szabályozó 1024/2013/ EU tanácsi rendeletben (EU [2013]) lefektetett feltételek teljesülését vizsgálja, vagyis a nem euróövezeti tagállamoknak dönteniük kell arról, hogy kérik-e a szoros együttmüködés kialakítását a bankunióval, vagy sem. A döntést nehezíti, hogy a bankunió felépítése és müködési struktúrája még számos bizonytalanságot hordoz (Moloney [2014]). A kérdésre az euróövezeten kívüli kelet-közép-európai tagállamok eltérő választ adnak. Jelenlegi pozíciójukat az 1. táblázat foglalja össze.

\section{1. táblázat}

A hat kelet-közép-európai tagállam 2019. márciusi pozíciója a bankunióhoz való csatlakozással kapcsolatban

\begin{tabular}{ll}
\hline Ország & \multicolumn{1}{c}{ Pozíció } \\
\hline Bulgária & $\begin{array}{l}2018 \text { júliusában hivatalosan kérte egyidejű csatlakozását } \\
\text { az ERM-2 rendszerhez és a bankunióhoz } \\
\text { csatlakozás } \\
\text { Románia }\end{array}$ \\
$\begin{array}{l}\text { Horvátország } \\
\text { Cseh Köztársaság, Magyarország euró bevezetésével egy időben való csatlakozás } \\
\text { és Lengyelország }\end{array}$ & $\begin{array}{l}\text { kivárás (gyakorlatilag vagy az ERM-2-höz, vagy az } \\
\text { euróövezethez való csatlakozással összekötött csatlakozás) }\end{array}$ \\
\hline
\end{tabular}

Az 1. táblázat alapján látható, hogy a kelet-közép-európai országok nem egységesek a bankunióhoz való csatlakozás megítélésében. A témával foglalkozó szakirodalom és az egyes országok elemzései is különbözően érvelnek és különbözőképpen ítélik meg azt, hogy vajon a kelet-közép-európai országoknak érdekében áll-e a bankunióhoz való gyors, önkéntes csatlakozás. Többen érvelnek amellett, hogy a kelet-közép-európai országok bankrendszerében meglévő magas külföldi tulajdoni hányad és egyéb strukturális jellemzők miatt ezeknek az országoknak érdekük a bankunióhoz való

\footnotetext{
${ }^{1}$ Vagyis azok a bankok is, amelyeknek a válságkezelése nem tartozik az SRM hatókörébe. Ezek a bankok a hozzájárulásukkal a pénzügyi stabilitásért mint externáliáért fizetnek, vagyis a hozzájárulás a Pigou-adók körébe tartozik.
} 
csatlakozás (Darvas-Wolff [2013], Hüttl-Schoenmaker [2016]). Ugyanezen strukturális sajátosságokból kiindulva mások amellett érvelnek, hogy magas külföldi tulajdonlás mellett csak a kívülmaradás ad lehetőséget a felügyeleti autonómia megörzésére (Spendzharova [2014]). A kelet-közép-európai országok bankrendszerének strukturális sajátosságai helyett azok bankpolitikáját elemezve Mérö-Piroska [2016] amellett érvel, hogy a belépési szándékot az indokolhatja, hogy az érintett államoknak gyenge a pénzügyi stabilitás fenntartására irányuló képessége, míg a többi állam esetében a távolmaradás indoka a bankrendszer erős állami kontrollálásának az igénye, vagyis a banknacionalizmus lehet. Az egyes országok kormányainak és jegybankjainak érvelését pedig a bankunióhoz való viszonyulásuk határozza meg.

A közép-kelet-európai országok mellett a két nem euróövezeti skandináv ország, Dánia és Svédország számára is fontos kérdés, hogy csatlakozzanak-e a bankunióhoz. ${ }^{2}$ Ellentétes oldalról indulva, ma mind a két ország a kérdés újbóli átgondolásánál tart. Dánia a kezdetektöl fogva kinyilvánította, hogy pozitívan viszonyul a csatlakozás kérdéséhez, amit Howarth-Quaglia [2013] (108. o.) „pozitív kivárásként” jellemez. A döntést Dánia 2019 őszére halasztotta. ${ }^{3}$ Svédország álláspontja szintén a kezdetektől határozott volt, nemet mondott a csatlakozásra, a brexit és Dánia pozitív viszonyulása azonban később elbizonytalanította. ${ }^{4}$ Ezt a bizonytalanságot tovább fokozta az, hogy a legnagyobb svéd székhelyü bank, a Nordea a bankunió felügyelete alá kívánt kerülni. ${ }^{5}$

A cikk következő részében röviden bemutatjuk a bankunión belüli felügyeleti és válságkezelési rendszereket és azokat az eltéréseket, amelyek ezen belül az önként csatlakozó euróövezeten kívüli tagállamokra vonatkoznak. Ezt követi hat keletközép-európai ország bankrendszereinek rövid elemzése - a hangsúlyt a banki struktúrákra és a bankpolitikákra helyezve -, majd a szakirodalom feldolgozásával bemutatjuk a bankunióhoz való csatlakozás mellett és az ellen szóló érveket, valamint a hat közép-kelet-európai ország bankunióval kapcsolatos álláspontját. A cikk fő következtetése, hogy az - euróövezetbe való belépést megelöző - bankunióhoz való csatlakozás kérdése igen összetett, a jelenlegi körülmények között nincs rá egyértelmü jó válasz.

\section{Bankfelügyelet és bankválságkezelés a bankunióban}

A bankunión belül az Európai Központi Bank az egységes mikroprudenciális felügyeleti hatóság, ami azt jelenti, hogy felügyeleti döntései a bankok számára kötelezők és jogilag kikényszeríthetök. A közvetlenül felügyelt bankok esetében a felügyeletet az úgynevezett közös felügyeleti csoportok látják el, amelyeknek az EKB és a nemzeti

\footnotetext{
${ }^{2}$ Az Egyesült Királyság bankunióval kapcsolatos elutasító álláspontját a brexit miatt nem elemezzük.

${ }^{3}$ Reuters, 2017. július 4.

${ }^{4}$ Reuters, 2017. július 10.

${ }^{5}$ A Nordea, Európa egyik legnagyobb bankja jelentősen átalakította a szervezeti struktúráját annak érdekében, hogy a bankunió felügyelete alá kerüljön. A székhelyét áttette Finnországba, miközben svéd, dán és norvég leányvállalatait fióktelepekké alakította át.
} 
felügyeleti hatóságok képviselői is a tagjai, de a vezetője minden esetben az EKB képviselöje. A kisebb, közvetetten felügyelt bankok esetében a felügyeleti tevékenységet továbbra is a nemzeti felügyeleti hatóságok végzik, de minden fontos módszertani kérdésben szorosan együttmüködnek az EKB-val. Az EKB-nak arra is van joga, hogy kezdeményezze a nemzeti hatóságoknál, hogy büntetést szabjanak ki. Emellett, ha olyan problémát észlel, amely ezt indokolja, az EKB közvetlen felügyelete alá vonhatja a bankunió bármelyik bankját. Ezen túlmenően a bankunióban az EKB az egyetlen engedélyező hatóság. Ez a tevékenysége nem korlátozódik a jelentős bankokra, minden egyes banki engedély kiadása és visszavonása, valamint a bankokban befolyásoló tulajdonrész szerzésének engedélyezése is az EKB jogosítványa. Mikroprudenciális felhatalmazásai mellett az EKB-nak részleges makroprudenciális jogosítványai is vannak. Joga van a nemzeti makroprudenciális hatóságok intézkedéseinek megkérdőjelezésére és megkifogásolására, valamint arra is, hogy magasabb tőkepuffereket írjon elő, mint a nemzeti hatóságok, vagy szigorítsa azok bizonyos intézkedéseit. Az EKB mint az euróövezet bankjainak végső hitelezője arra is jogosult, hogy likviditási segítséget nyújtson az arra rászoruló bankoknak, de - monetáris politikai felhatalmazásával összhangban - csak az euróövezeti bankok esetében. ${ }^{6}$

Az EKB legfőbb döntéshozó testülete a kormányzótanács. A felügyeleti feladatok döntéshozatalához egy új testületet állítottak fel - a felügyeleti tanácsot -, amelyben a bankunió minden egyes tagállamának van képviselöje. A felügyeleti tanács kezdeményezi és készíti elő az egységes bankfelügyeleti rendszer összes döntését, amivel kapcsolatban a kormányzótanácsnak egyetértési joga van, vagyis a felügyeleti kérdésekben is a kormányzótanácsé a végső szó. Ugyancsak a kormányzótanács határozza meg az EKB-nak a felügyeleti kérdésekkel kapcsolatos általános müködési elveit.

A nem euróövezeti tagállamok csatlakozásuk esetén a felügyeleti jogkört átengedik az EKB-nak, de nem teljesen ugyanolyan feltételekkel, mint a monetáris unió tagállamai. A két legfontosabb különbség, hogy nem kapnak képviseletet a kormányzótanácsban, és semmiképpen nem részesülhetnek az EKB likviditásisegítség-nyújtásában.

Az egységes válságkezelési mechanizmus (SRM) csak az egységes bankfelügyeleti rendszer (SSM) által felügyelt bankok szanálását végezheti. Vagyis a bankunióhoz való csatlakozás egyidejűleg jelenti a bankunió első és második pilléréhez való csatlakozást is, nem lehet csak az egyik pillérhez csatlakozni. Az SRM tagjai a brüsszeli székhelyü egységes szanálási hatóság (SRB) és a minden tagállamban kötelezően felállított nemzeti szanálási hatóságok. Az SRM felelössége az SSM összes (közvetlenül és közvetve felügyelt) bankjának a szanálása. Ha egy bank megbukna, vagy az EKB észlelné, hogy a bukása erősen valószínü, akkor az EKB haladéktalanul értesíti az SRB-t, amely dönt arról, hogy az adott bankot szanálják-e, vagy sem. A szanálásról szóló pozitív döntés esetén az SRB fogadja el a konkrét szanálási tervet az SRM által lefedett intézményi körre vonatkozóan, míg azon intézmények esetében, amelyek nem tartoznak az SRM

\footnotetext{
${ }^{6}$ A pénzmosás elleni küzdelem nem tartozik az egységes bankfelügyeleti rendszer (SSM) mandátumai közé. Ezt azért érdemes megjegyezni, mert a Baltikum és a skandináv országok bankrendszereinek 2017-től kibontakozó pénzmosási botránya során felmerült az EKB felelősségének kérdése is. A pénzmosás elleni küzdelem hatékonyságának megerősítésére a Bizottság számos javaslatot dolgozott ki (EB [2018]), de azt továbbra sem tervezi beemelni a bankunió keretei közé.
} 
közvetlen hatáskörébe, ez a nemzeti szanálási hatóságok feladata. Ezenfelül, ha egy nemzeti szanálási hatóság intézkedésének végrehajtásához szükség lenne az Egységes Szanálási Alap (Single Resolution Fund, SRF) forrásainak igénybevételére is, akkor a szanálási terv elfogadása mindenképpen az SRB feladatává válik. Magát a szanálást a nemzeti szanálási hatóságok végzik. A szanálás egységes kezelése és eredményes müködése érdekében az SRB általános ajánlásokat adhat ki.

Az SRB kezeli a szanálás legfőbb pénzügyi forrását jelentő Egységes Szanálási Alapot. Az SRF a bankok és bizonyos befektetési alapok befizetéséből képződik, vagyis az SRF-ből való szanálás költségét maguk az érintettek viselik, az nem terheli a közpénzeket. Az SRF megcélzott nagysága legalább a biztosított banki betétek egy százalékát teszi majd ki (ez mintegy 55 milliárd eurós összeget jelent). Működésének első nyolc évében, a 2016-2023 közötti időszakban a bankok a hozzájárulásukat elkülönített „nemzeti rekeszekbe” fizetik be, amelyeket fokozatosan olvasztanak össze egységes európai alappá.

A szanálásra vonatkozó európai szabályoknak megfelelően ${ }^{7}$ az SRF forrásait kizárólag az úgynevezett belső feltőkésítés (bail-in) után lehet felhasználni. ${ }^{8}$ Vagyis a szanálás során az SRF a második a veszteségek fedezésére felhasználható források sorában. Az SRF-ből felhasználható források mértékének felső határa a bajba került bank idegen forrásainak öt százaléka. Amennyiben még ez is kevésnek bizonyulna, az Európai Stabilitási Mechanizmus (European Stability Mechanism, ESM) adhat további forrásokat közvetett (a bank székhely szerinti államán keresztüli) vagy közvetlen feltőkésítés formájában. Ez azonban a bankoknak már csak egy szükebb körére vonatkozó lehetőség, csak azokat a bankokat tőkésítheti fel az ESM, amelyek vagy az egész EU, vagy valamelyik tagállam pénzügyi piacainak szempontjából komoly rendszerkockázatot jelentenek.

A közvetett feltőkésítés természetesen csak időleges lehetőség, miután a tagállami szanálási források összeolvadása megtörtént, ez a megoldás kiesik a lehetséges feltőkésítési eszközök köréből. A bankok feltőkésítésében játszott szerepe mellett a jövőben az ESM nyújthat további finanszírozást az SRM esetlegesen hiányos forrásainak kiegészítésére. ${ }^{9}$ Az SRB nemcsak a bankok feltőkésítéséről dönthet, hanem alkalmazhatja a bankszanálási eszköztár egyéb elemeit is. ${ }^{10}$ Az SRB-n belül kétféle döntéshozatali mechanizmus van. A plenáris ülés - hasonlóan az EKB kormányzótanácsához - a legmagasabb szintű döntéshozó testület, ahol az általános iránymutatásokról döntenek, és amely évente legalább kétszer ülésezik. A konkrét szanálási döntéseket - beleértve az SRF pénzügyi forrásainak felhasználását is a végrehajtó testület hozza meg.

${ }^{7}$ Ezek: az SRM-ről szóló 806/2014/EU rendelet és a bankok helyreállításáról és szanálásáról szóló 2014/59/EU irányelv (Bank Recovery and Resolution Directive, BRRD).

${ }^{8}$ A bankok megsegítésére fordított közpénzek minimalizálása érdekében először a belső feltőkésítést kell alkalmazni. Ez azt jelenti, hogy - legfeljebb a bebukott bank idegen forrásainak 8 százalékos mértékéig - a bank bizonyos, előre definiált forrásait részvénnyé kell átalakítani, illetve le kell írni.

${ }^{9}$ Erről az euróövezeti csúcstalálkozó 2018. június 29-i ülésén döntött. Az ESM által nyújtott kisegítő finanszírozás olyan hitel formájában történik, amelyet a bankszektornak kell visszafizetni.

${ }^{10}$ A BRRD szerint ezek: eszközök elkülönítése; vagyonértékesítés, áthidaló intézmény alkalmazása. 
Az SRM-en belül az euróövezet tagállamai és az önkéntesen csatlakozók ugyanolyan jogokat élveznek, minden ország ugyanúgy van képviselve a döntéshozó testületekben, és abban sincs különbség, hogy az SRF forrásait hogyan lehet felhasználni velük kapcsolatban. Egy igen lényeges különbség mégis van abban a tekintetben, hogy milyen szanálási lehetőségek vonatkoznak a két országcsoport bankjaira, mert az ESM forrásainak felhasználására csak az euróövezeten belül van lehetőség.

\section{A nem euróövezeti kelet-közép-európai országok bankrendszere - banki struktúrák és bankpolitika}

Az általunk elemzett hat ország bankrendszere számos hasonlóságot és több lényeges eltérést is mutat. Az Európai Unióhoz való csatlakozás idejére a hat kelet-középeurópai ország (KKE6) bankrendszere döntő többségében külföldi tulajdonba került. A tulajdonosok jellemzően az EU nagybankjai voltak. Bulgária és Románia speciális ebben a tekintetben, mert mindkét országban a görög bankok is megjelentek tulajdonosként. A válságot megelőző időszakban a külföldi tulajdoni hányad lényegét tekintve nem változott, mindegyik országban a 60-90 százalékos sávban mozgott. A külföldi bankok szerepe az utóbbi években Magyarországon és Lengyelországban jelentősen visszaszorult, mivel mindkét ország kormánya célként fogalmazta meg és támogatta a bankrendszer hazai tulajdonlásának erősítését. A KKE6-bankok közül egyedül a magyar OTP Banknak van számottevő külföldi tevékenysége. Így a KKE6 esetében a külföldi bankok befelé irányuló tevékenysége jóval nagyobb, míg a hazai bankok kifelé irányuló tevékenysége az euróövezet bankrendszereire jellemző értékeknél jóval kisebb.

A válság előtti időszakban a külföldi anyabankok nemcsak a müködéshez szükséges tőkét biztosították leánybankjaiknak, de jelentős mértékü likviditást is nyújtottak a számukra, vagyis a válság előtti hitelezési expanziót jelentős mértékben az anyabanki források finanszírozták. Ez a válság előtt extrém módon magas hitel/betét arányt eredményezett több kelet-közép-európai országban, különösen Bulgáriában, Magyarországon és Romániában, de a csúcsértékek Horvátországban és Lengyelországban is meghaladták a 100 százalékot (1. ábra).

Mind a hat ország bankrendszere erősen, de nem kiugróan koncentrált. Az öt legnagyobb bank piaci részesedésével mérve, a bankszektorok koncentráltsága igen széles tartományban mozog az EU-ban. Hat országban 80 százalék feletti a részarányuk, négyben pedig 40 százalék alatti. A hat kelet-közép-európai ország 48 és 86 százalék közötti értékeivel jól illeszkedik az euróövezet országaira jellemző értékekhez. Mind a hat országban alacsony a bankok pénzügyiközvetítö-szerepe az euróövezet országaira jellemző értékekhez képest. Az EU-csatlakozást követően mindegyik országban jelentősen nőtt a bankok hitelezési tevékenysége, a válság éveiben azonban különböző hitelezési pályákat jártak be. A banki pénzügyi közvetítés mélyülése folytatódott Lengyelországban, nagyjából változatlan maradt a Cseh Köztársaságban, míg a másik négy országban, amelyeket sokkal jobban sújtott a válság, a hitelezés jelentős visszaszorulása volt megfigyelhető (2. ábra). 


\section{1. ábra}

Hitel/betét arány, 2004-2016 (százalék)

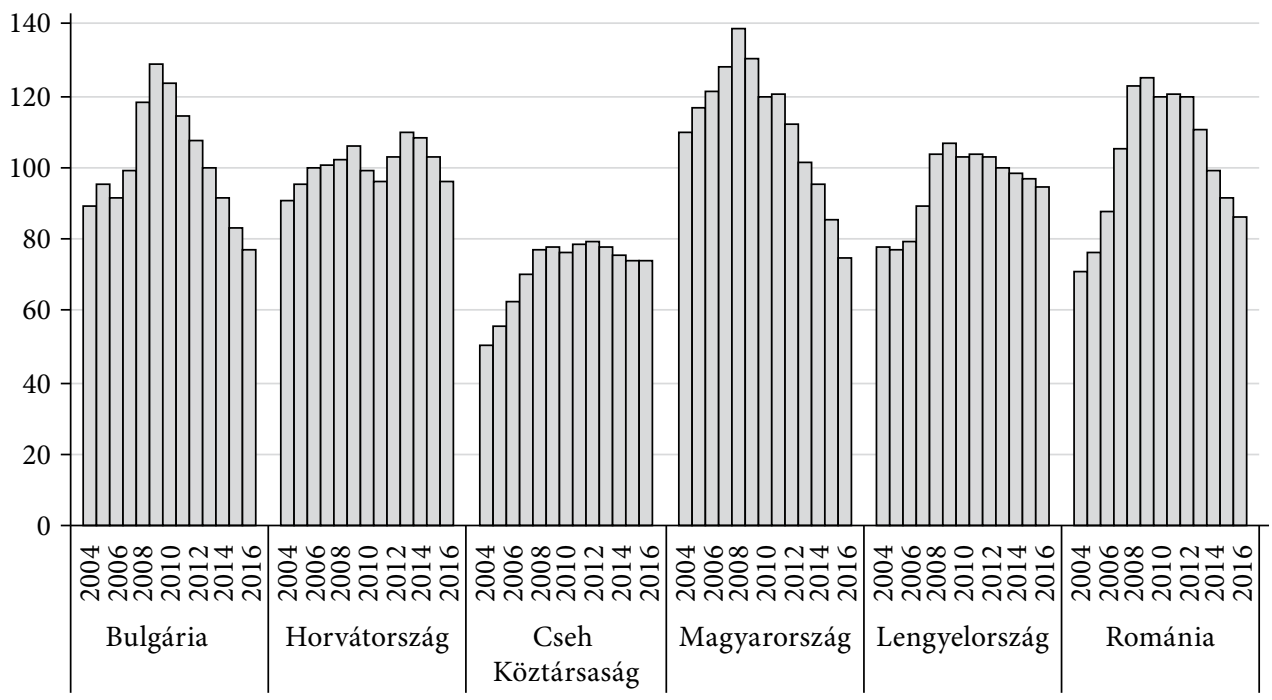

Forrás: a Világbank Global Financial Development adatbázisa.

\section{2. ábra}

A bankok által a magánszektornak nyújtott hitelek állománya a GDP százalékában, 2004-2016

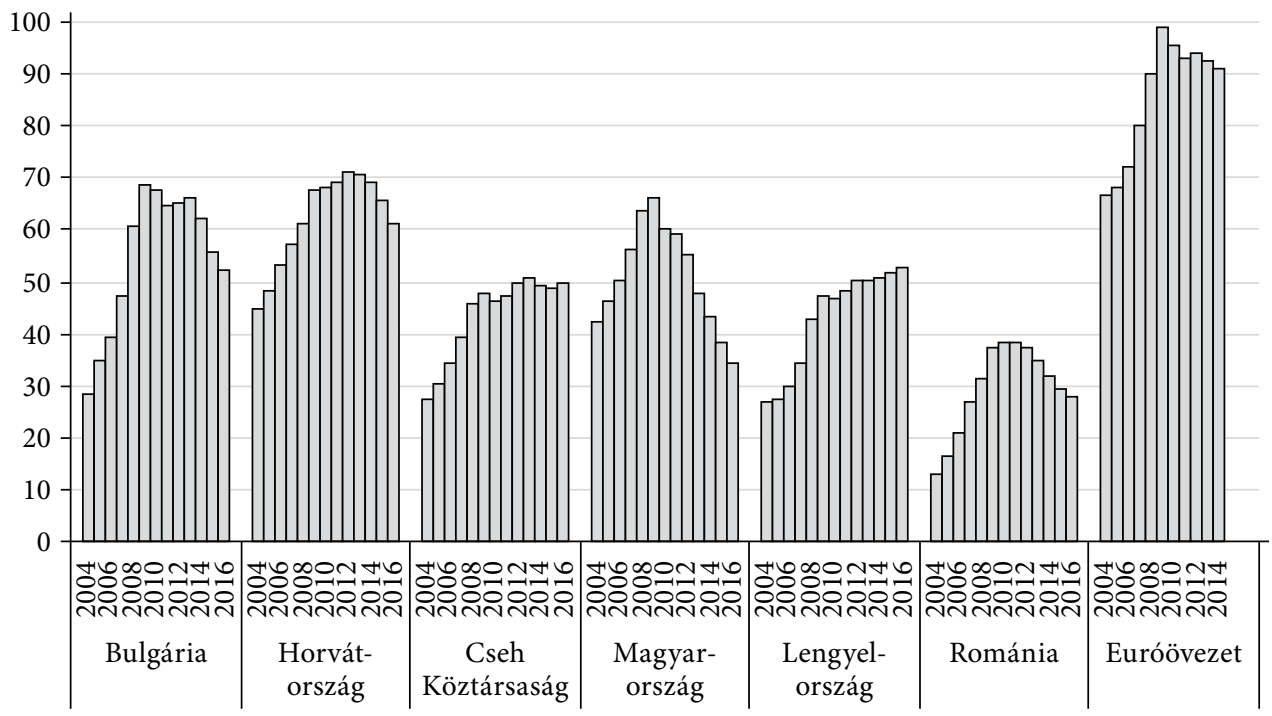

Forrás: a Világbank Global Financial Development adatbázisa.

A KKE6 bankjainak jövedelmezősége kiemelkedően magas volt a válságot megelőző években, számottevően meghaladta az euróövezetre jellemző értékeket. A válság alatt különösen a horvát, a magyar és a román bankrendszer szenvedett el nagy 
veszteségeket, amihez mindhárom országban számottevően hozzájárult, hogy a válság előtt nyújtott lakossági devizahitelek igen nagy arányban váltak nemteljesítővé. A válságperiódusban megmutatkozó jövedelemcsökkenés ellenére a cseh és a lengyel bankok tőkemegtérülése (RoE) folyamatosan kimagasló maradt. A jövedelemcsökkenés folyamata a 2010-es évek közepére állt meg, és mára - hasonlóan a válságot megelőző időszakhoz - számottevően magasabb a KKE6 bankrendszereinek jövedelmezösége, mint az EU-ra jellemző bankszektori átlag, elsősorban az euróövezet bankrendszerének lassú helyreállítási periódusa miatt (3. ábra).

3. ábra

A bankrendszer RoE mutatója, 2007-2016 (százalék)

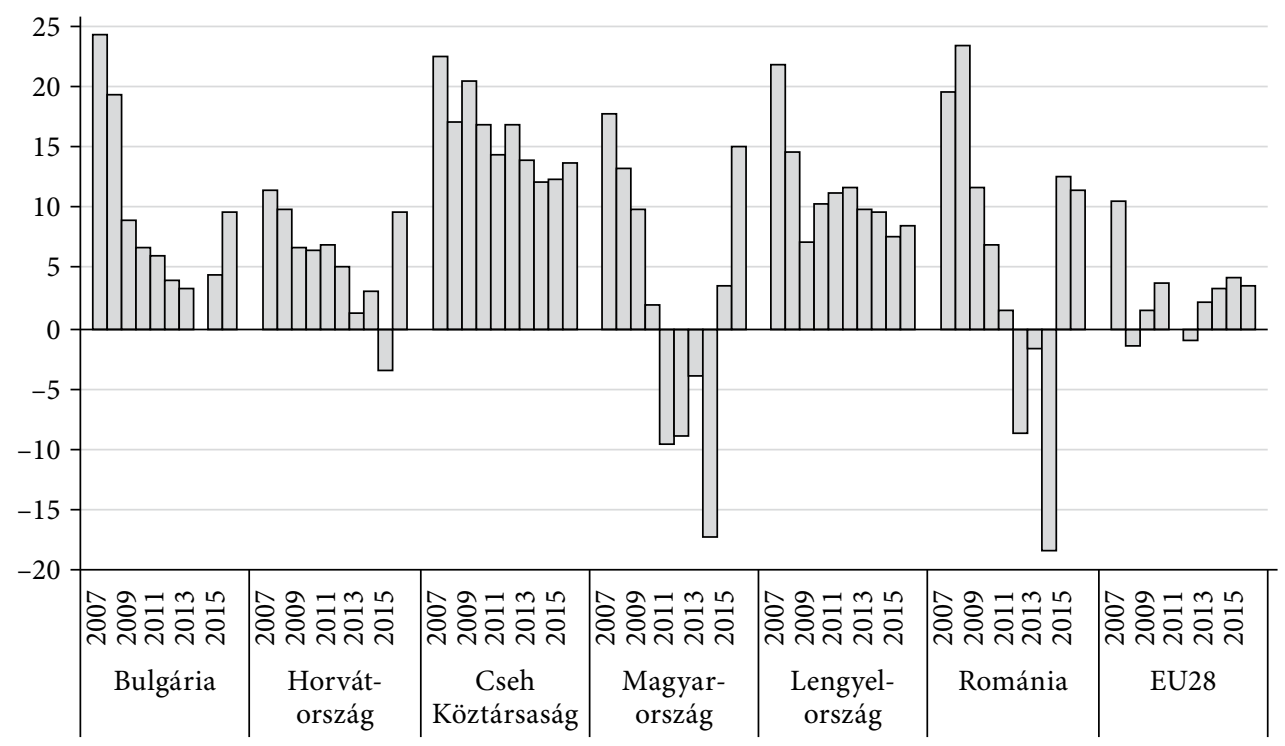

Forrás: a Világbank Global Financial Development adatbázisa és az Európai Bankföderáció.

A válságot megelőző időszakban a KKE6 bankjainak eszközminősége, a román bankszektor kivételével, jó volt, a nemteljesíto hitelek aránya 2,4 százalék (Bulgária) és 4,9 százalék (Horvátország) között mozgott. A Cseh Köztársaságban és Lengyelországban, mivel ezt a két országot nem érintette súlyosan a válság, a nemteljesítő hitelek aránya folyamatosan alacsony maradt, míg a másik négy országban a válság alatt számottevően megugrott. 2016-ra mindegyik országban elindult a hitelminőség javulása, bár Bulgáriában és Horvátországban még ekkor is 10 százalék feletti értéket vett fel (4. ábra).

A KKE6 bankrendszereinek általános stabilitása a $Z$-mutatóval mérve stabil, ${ }^{11}$ de jóval kevésbé, mint az euróövezet jobban teljesítö bankrendszereié, amelyeket 15-25 közötti sávban mozgó $Z$-érték jellemez. A legstabilabb bankrendszerü Cseh Köztársaság

${ }^{11}$ A Z-mutató egy előretekintő szemléletű stabilitási mutató, amely közvetlenül hasonlítja össze a kockázatot (amit a RoA volatilitásával mér) és a kockázatok elnyelésére szolgáló pufferek nagyságát (vagyis a puffereket és a megtermelt profitot). Minél nagyobb a $Z$-érték, annál stabilabb a bankrendszer (Cihák és szerzőtársai [2012]). 
4. ábra

A nemteljesítő hitelek aránya a teljes hitelportfólión belül, 2007-2016 (százalék)

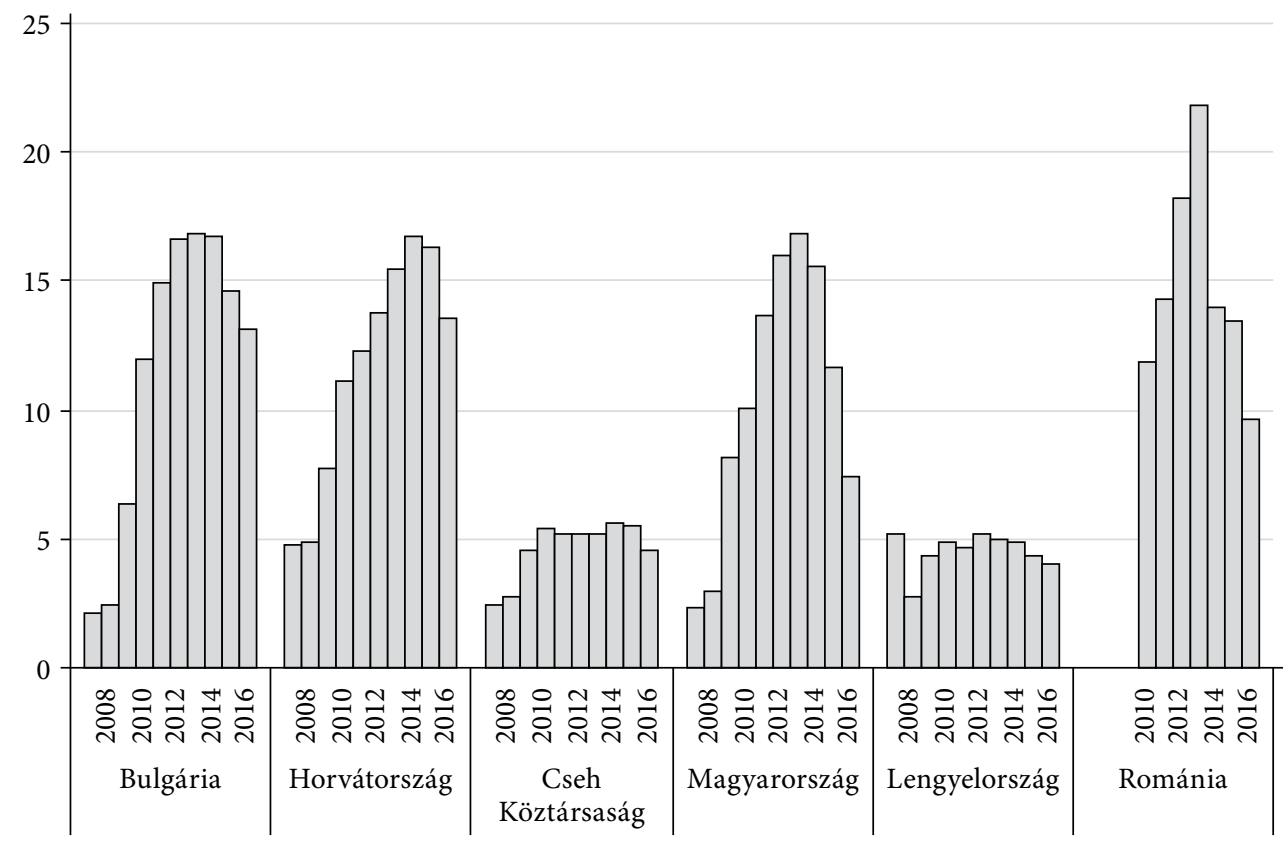

Forrás: a Világbank Global Financial Development adatbázisa.

Z-értéke igen közel van az euróövezet országaira jellemző értékekhez, míg a másik öt ország bankrendszerének stabilitása igen hasonló (5. ábra). Külön ki kell emeljük a bolgár bankrendszer stabilitását, hiszen Bulgáriában 2014-ben két nagybank is csődbe ment. Utólagosan értékelve ${ }^{12}$ a bolgár bankrendszer stabilitását, a $Z$-érték egyenletes alakulása a két bankcsőd egyedi, nem rendszerkockázati jellegét mutatja.

A válságot megelőzően mind a hat ország bankpolitikáját az jellemezte, hogy bankpiacukat megnyitották a külföldi bankok számára. A szocialista monobankrendszer örökségeként mind a bankok fejlesztéséhez szükséges tőke, mind a szakértelem hiányzott a régióban. Ezért mind a hat országnak szüksége volt a tőkeerős, nagy szakmai tapasztalattal és jó reputációval rendelkező külföldi bankokra mint a hazai bankokba befektető tulajdonosokra. A kelet-közép-európai országok, Horvátország kivételével, még a válság elött csatlakoztak az EU-hoz, de e tekintetben bankpolitikájukban a csatlakozás sem hozott változást. A kelet-közép-európai országok abban is elkötelezettek voltak, hogy bankszabályozásukat már az EU-csatlakozás előtt a nemzetközi (bázeli) szabványoknak megfelelően alakították át, így a csatlakozáshoz kötődő szabályozási változásokat is könnyedén tudták megvalósítani. A válság alatt azonban a keletközép-európai régió bankjainak a külföldi anyabankok által biztosított tőkétől és likviditástól való függése már pénzügyi stabilitási kockázatot jelentett, hiszen számos

${ }^{12}$ A Világbank Global Financial Development adatbázisának 2016-os változatában eredetileg még -12,6 volt a bolgár bankszektor $Z$-értéke. 


\section{5. ábra}

A hat kelet-közép-európai ország bankrendszerének $Z$-értéke

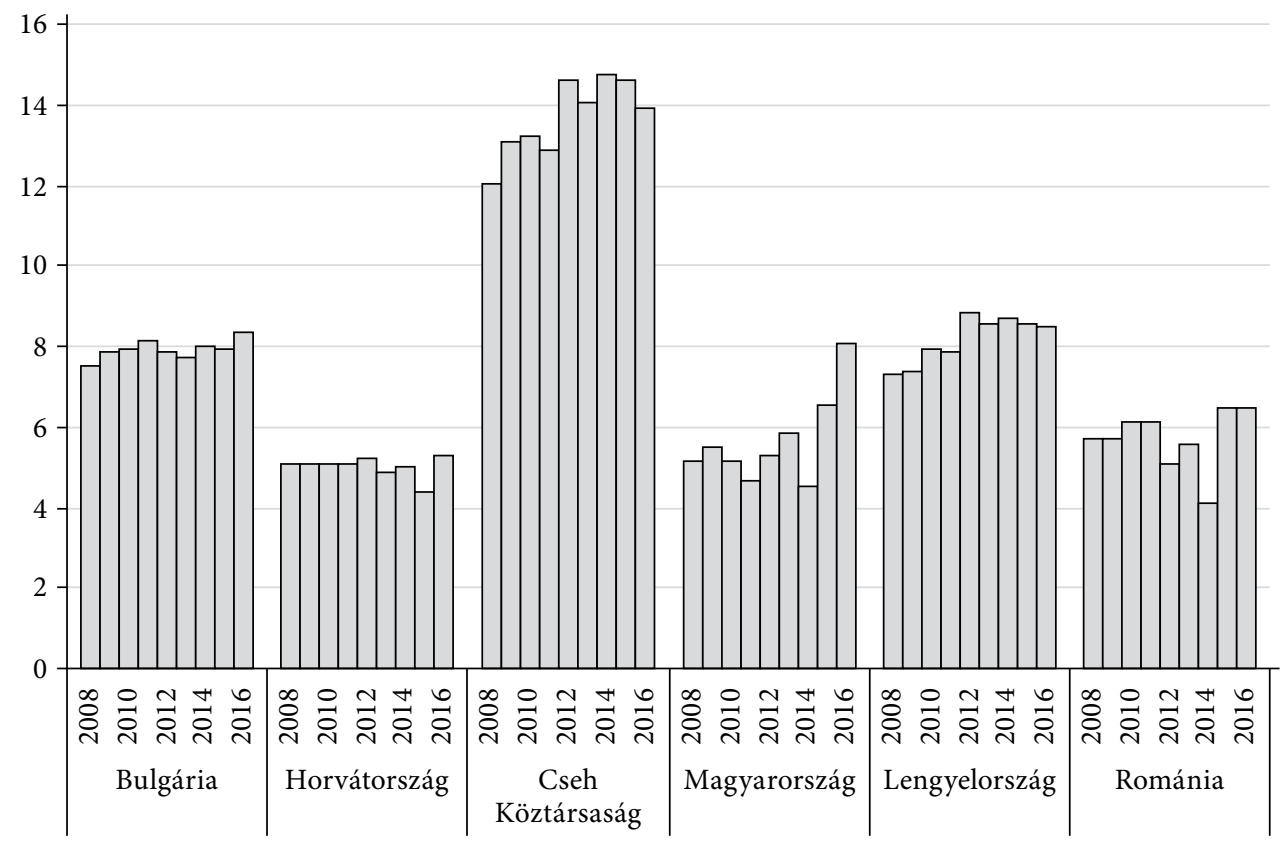

Forrás: a Világbank Global Financial Development adatbázisa.

esetben maguk az anyabankok is kormányzati segítségre szorultak. Ezt a kérdést volt hivatott kezelni a Bécsi Kezdeményezés, ${ }^{13}$ amelynek keretében számos európai nagybank kinyilvánította a leánybankjai iránti erős elkötelezettségét, és ígéretet tett arra, hogy biztosítják számukra a veszteségeik fedezéséhez és a stabil müködéshez szükséges tőkeemelést és forrásokat. Mindezzel együtt az euróövezeti szuverén és bankválságok hatására az anyabankok jelentősen mérsékelték hitelezési aktivitásukat mind a hazai, mind a külföldi piacokon. A kelet-közép-európai régióban azonban erősebben csökkentették a hitelezést, mint saját belföldi piacaikon (Vienna Initiative [2018]). A KK6-országokból való forráskivonás nem hirtelen történt meg, hanem kellö fokozatossággal, ami az ezekre a piacokra jellemző gyenge hitelkereslettel együtt lehetőséget adott a KKE6-bankok forrásoldali alkalmazkodására. Hogy ez mennyiben volt a Bécsi Kezdeményezés hatása, az erősen kérdéses. Epstein [2013] amellett érvel, hogy a bankok elkötelezettsége nem a Bécsi Kezdeményezés következménye, hanem az anyabankoknak a régió iránti erős stratégiai elkötelezettsége. Ezt az érvelést erősíti az

\footnotetext{
${ }^{13}$ Az Európai Bankkordinációs (Bécsi) Kezdeményezést (The European Bank Coordination "Vienna" Initiative, EBCI) 2009-ben hozták létre. Ez egy olyan informális koordinációs fórum, amelynek keretében az állami és a magánszektor szereplöi, valamint a nemzetközi pénzügyi intézmények egyeztetik lépéseiket Dél-, Kelet- és Közép-Európa pénzügyi stabilitásával kapcsolatban, aminek része az anyabankoknak a leánybankjaik likviditási és tőkehelyzetének támogatására vonatkozó elkötelezettsége is. Később, a második bécsi kezdeményezés fő célja a hitelezés rendezetlen módon való leépülésének megakadályozása lett (http://vienna-initiative.com).
} 
a tény is, hogy a Bécsi Kezdeményezésből kimaradó Cseh Köztársaság és Lengyelország e tekintetben semmivel sem volt rosszabb helyzetben, mint a részt vevő országok (de Haas és szerzőtársai [2012]). Bármi is motiválta az anyabankok fokozatos forráskivonását, tény, hogy a kelet-közép-európai régió bankjai egyre kevésbé a külföldi és egyre inkább a hazai forrásbevonásra támaszkodtak. A válság nyomán Magyarországon és Lengyelországban - összhangban azzal, hogy mindkét országban nacionalista politikai erők kerültek hatalomra - a bankpolitikát is a banknacionalizmus kezdte meghatározni (Johnson-Barnes [2015], Mérö-Piroska [2016]). A kormányok kinyilvánították arra vonatkozó preferenciájukat, hogy a bankrendszer többségi hazai tulajdonba kerüljön, és aktívan támogatták is az erre irányuló tranzakciók megvalósulását. A hagyományosan euroszkeptikus Cseh Köztársaságban nem a hazai tulajdonlás térnyerésének támogatása, hanem a külföldi tőke és likviditás országon belül tartása („körbekerítése”) jelentett új bankpolitikai irányvonalat a válság kapcsán, ami hasonló irányú bankpolitikai elmozdulást jelent. A tőke és likviditás körbekerítésének jelei Horvátországban is megtalálhatók (Mérö-Piroska [2017b]). A banknacionalizmus és az euroszkepticizmus is azok között a tényezők között van, amelyek meghatározzák a KKE6-országok bankunióhoz való viszonyát, ahogy azt a későbbiekben bemutatjuk.

\section{Érvek és ellenérvek a KKE6-országok bankunióhoz való csatlakozásával kapcsolatban}

Ebben a részben a KKE6 országai szempontjából vizsgáljuk a bankuniót. Ez a kérdés nemcsak ezen országcsoport számára fontos: az euróövezet egésze számára is fel lehet tenni a kérdést, hogy vajon előnyös-e ennek az országcsoportnak a csatlakozása az euróövezet számára, vagy sem. A bankunió iránti igényt az euróövezet válsága teremtette meg, mivel nyilvánvalóvá vált, hogy az eurót és az euróövezet pénzügyi stabilitását együttesen csak az euróövezet szintjén alkalmazható eszközökkel lehet megvédeni, vagyis az euróövezet stabilitásának védelméhez a közös monetáris politika mellett a pénzügyi stabilitásért viselt közös felelösségre és az ehhez tartozó hatékony közös eszköztárra is szükség van. Ennek megfelelöen Beck [2012] amellett érvel, hogy a bankunióra sokkal inkább a monetáris unió szintjén van szükség, hiszen így állítható helyre a monetáris politika és a pénzügyi stabilitás közötti összhang. Mások amellett érvelnek, hogy az EU egységes piaca nem müködhet hatékonyan, ha a bankpiac nem egységes, ezért a bankunióra az egész EU szintjén van szükség (Constancio [2013], Montanaro [2016], Mérö-Piroska [2018]). A bankunió konstrukciója nem egyértelmü ezzel kapcsolatban: ahogy ezt korábban bemutattuk, lehetővé teszi a nem euróövezeti országok csatlakozását, de az euróövezeti tagokhoz képest kedvezőtlenebb feltételekkel, vagyis maga a bankunió ebben a kérdésben megengedő, de nem támogató.

A bankunióhoz való csatlakozás legfontosabb előnyei a KKE6 országai számára: a pénzügyi integráció szorosabbá tétele; a jobb, megbízhatóbb és nagyobb tekintélyü felügyeleti rendszer; az olcsóbb forráshoz jutás lehetősége (ami csökkentheti a hitelezési költséget is), az Egységes Szanálási Alaphoz való hozzáférés és a függetlenebb szanálási gyakorlat, valamint a bankunió jövőjének alakításában való részvétel lehetősége 


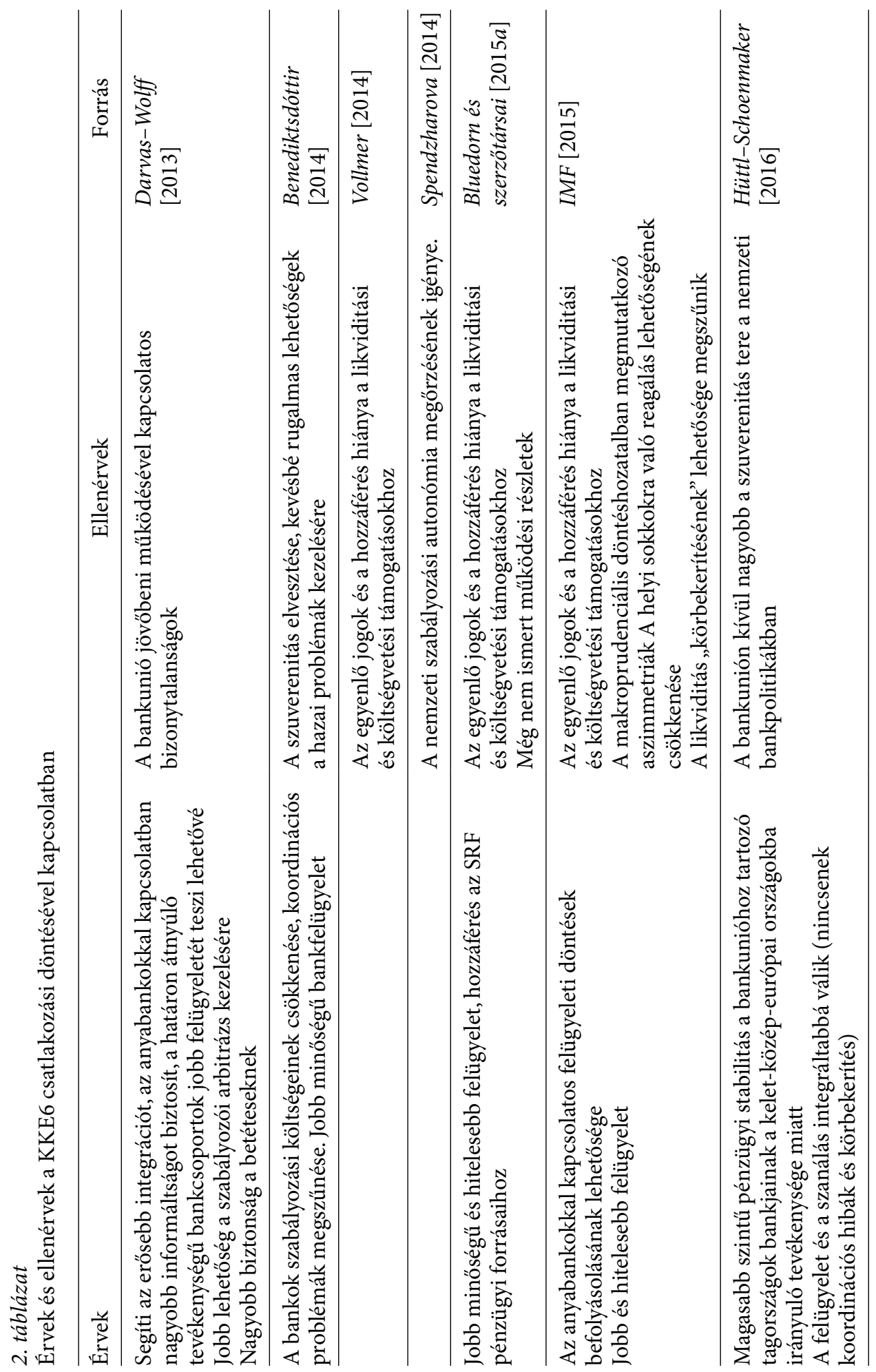




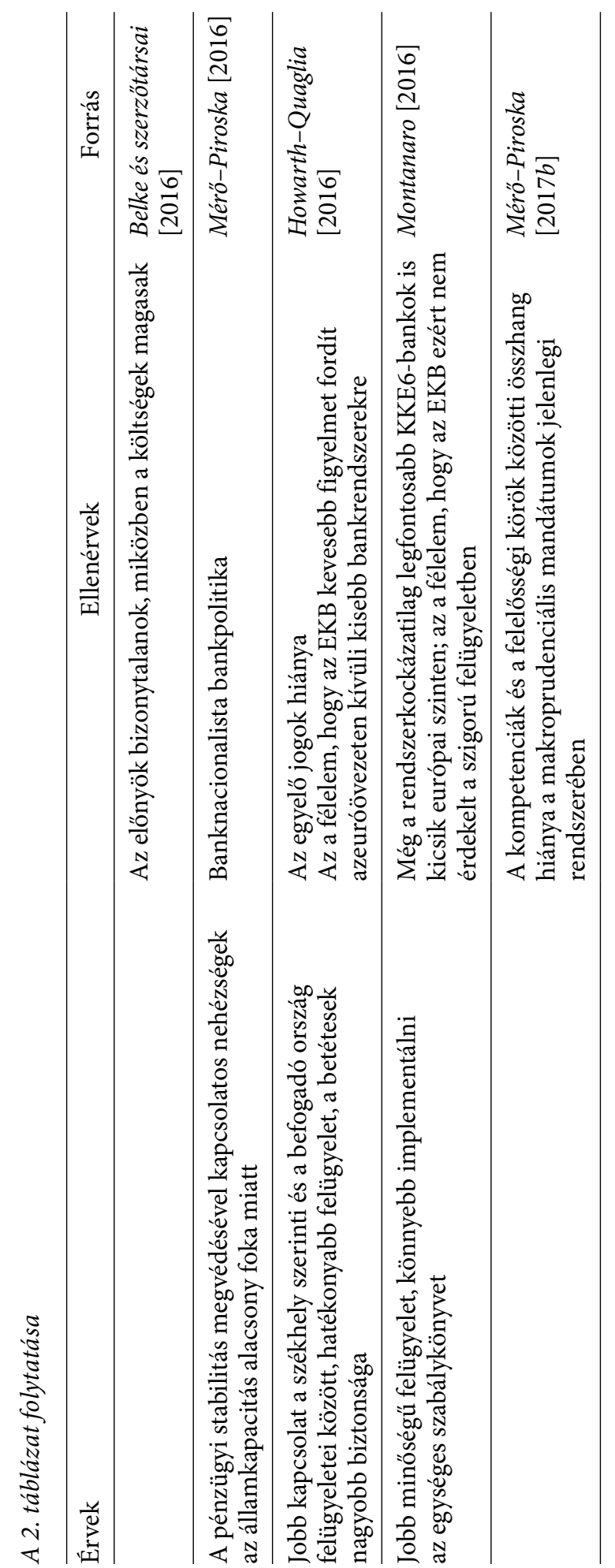


már az euró bevezetése elötti időszakban is. Másik oldalról a bankunióba való belépéssel kapcsolatos legfontosabb fenntartások az egyenlö jogok hiányára, a kompetenciák és a felelősség közötti megfelelés hiányára, az EKB likviditási eszközeihez és az ESM stabilitási eszközeihez való hozzáférés hiányára, valamint a nemzeti érdekek képviseletének nem megfelelö lehetőségére vonatkoznak. A 2. táblázatban összefoglaljuk a szakirodalomban megjelenö ${ }^{14}$ legfontosabb érveket és ellenérveket a KKE6 országainak bankunióhoz való csatlakozásával kapcsolatban.

A szakirodalomban nincs konszenzus arra vonatkozóan, hogy a KKE6 országainak érdemes-e belépnie a bankunióba az euróövezeti csatlakozást megelőzően. Van, aki amellett érvel, hogy az előnyök számottevően meghaladják a hátrányokat (DarvasWolff [2013], Benediktsdóttir [2014], Hüttl-Schoenmaker [2016]), míg mások éppen az ellenkezöjét gondolják (Vollmer [2014], Spendzharova [2014], Belke és szerzőtársai [2016]). Megint mások arra teszik a hangsúlyt, hogy a kelet-közép-európai országok döntésének alapja nem az elönyök és hátrányok mérlegelése, hanem sokkal inkább az országok bankpolitikája (Mérö-Piroska [2016], Howarth-Quaglia [2016]). Mindezeken túlmenően Bluedorn és szerzőtársai [2015b] három fontos kompromisszumot is megjelöl, amelyek komoly hatással lehetnek a kelet-közép-európai országok döntésére. Ezek: 1. a nemzeti bankpolitika kisebb rugalmassága versus hozzáférés a közös alapokhoz, 2. a határon átnyúló banktevékenység kontrollálásának csökkenő lehetősége versus a közös likviditási támogatásokhoz való hozzáférés, 3. a szanálás hazai kontrolljának csökkenése versus hozzáférés az Egységes Szanálási Alaphoz. Az első két kompromisszum esetében azonban - ahogy azt korábban bemutattuk a közös költségvetési és likviditási eszközökhöz való hozzáférés (még?) nem biztosított a bankunióhoz önkéntesen csatlakozó országok számára.

\section{A KKE6 és a bankunió}

A következőkben országonként tekintjük át a hat kelet-közép-európai ország bankunióhoz való csatlakozásra vonatkozó politikáját és álláspontját. A hat ország csatlakozásra vonatkozó pozícióját korábban az 1. táblázatban foglaltuk össze.

Bulgária - 2018-ban kérte egyidejü felvételét az ERM-2-be és a bankunióba

Az egy före jutó GDP-vel mérve Bulgária az EU legszegényebb országa. A Világbanknak a kormányzás szintjére vonatkozó nemzetközi adatbázisa ${ }^{15}$ szerint a KKE6 országcsoporton belül Bulgáriában a legrosszabb a jogállamiság és a korrupció helyzete. Bul-

\footnotetext{
${ }^{14}$ Azokat az irodalmakat, amelyek a hat kelet-közép-európai ország közül csak egyre vonatkoznak, kihagytuk a táblázatból, mert azokat a következő részben, az országonkénti elemzésnél dolgozzuk fel. Ugyancsak nem vettük figyelembe a kizárólag a kelet-közép-európai régión kívüli nem euróövezeti országok (Egyesült Királyság, Dánia és Svédország) csatlakozása melletti és elleni érvekre vonatkozó szakirodalmat sem.

${ }^{15}$ Worldwide Governance Indicators dataset (http://info.worldbank.org/governance/wgi/\#home).
} 
gária - Horvátországgal együtt - a legnagyobb arányú nemteljesítő hitelállománnyal rendelkezik (4. ábra), ami folyamatosan magas kockázati szintet jelent a bankszektor számára. 2012-ben, amikor a bankunió létrehozásáról szóló döntés megszületett, Bulgária még ellenezte a bankunióhoz való csatlakozást. 2014 júliusában az ország harmadik és negyedik legnagyobb bankja komoly bankpánikon ment keresztül, ami aláásta a bankszektor és a politikai helyzet stabilitását is. A stabilitás visszanyerése érdekében Roszen Plevneliev államfö bejelentette, hogy Bulgáriának szándékában áll csatlakozni a bankunióhoz. ${ }^{16}$ Azóta Bulgária következetesen kinyilvánítja, hogy szándékában áll a mielőbbi csatlakozás, annak ellenére, hogy bankrendszerét sikerült gyorsan stabilizálnia. A csatlakozás okai között a pénzügyi stabilitás megerösítése mellett az olcsóbb forráshoz jutás lehetöségét is hangsúlyozzák. ${ }^{17}$

2018. június 29-én a bolgár pénzügyminisztérium és a központi bank formálisan is kérelmezte az ERM-2 mechanizmushoz és a bankunióhoz való egyidejü csatlakozást, 2019. júliusi belépéssel. Az Eurócsoport ${ }^{18}$ és az EKB meghatározta azokat a feltételeket, amelyeket Bulgáriának teljesítenie kell ahhoz, hogy csatlakozhasson az ERM-2-höz és a bankunióhoz ( $E U$ [2018]). Ennek részét képezi az, hogy az EKB átfogóan értékeli a bolgár bank- és bankfelügyeleti rendszert, és ennek alapján Bulgária megvalósítja mindazokat a fejlesztéseket, amelyek a csatlakozás előfeltételei. Az Eurócsoport egy évet adott az EKBnak az átvilágítás lebonyolítására. Ennek részeként az EKB megkezdte a hat legnagyobb bolgár bank eszközminőségének átfogó elemzését és stressztesztelését. ${ }^{19}$ Ennek fényében, a KKE6 országai közül Bulgária lehet az első, amelyik csatlakozik a bankunióhoz.

\section{Cseh Köztársaság - kivárás}

A hat kelet-közép-európai ország közül a Cseh Köztársaság bankrendszere a legstabilabb. Nem érintette súlyosan a válság, így nem halmozott fel nagyarányú nemteljesítő hitelportfóliót, bankrendszeri $Z$-mutatója a fejlett, legstabilabb bankrendszerekkel rendelkező EU-országokhoz hasonló. Bankjai soha nem függtek túlzott mértékben az anyabanki forrásoktól, és folyamatosan kiemelkedően magas volt a bankok jövedelmezősége is (lásd 1-5. ábra). Kormányzási rendszere is a legjobban működik a hat ország közül: mind a jogállamiságra, mind a kormányzati müködés hatásosságra, illetve a szabályozás minőségére vonatkozó mutatói is a legjobbak, míg - a Világbanknak a kormányzás szintjére vonatkozó nemzetközi adatbázisa szerint - a korrupció kontrollja Lengyelország mögött a második legjobb a KKE6-ban. A cseh bankszabályozásban nagyon aktívan használják a nemzeti hatáskörben alkalmazható makroprudenciális eszköztárt, helyenként a külföldi tulajdonú bankok által nyújtott likviditás és töke körbekerítésére (Mérö-Piroska [2016]).

A cseh hatóságok részletes hatáselemzést végeztek a Cseh Köztársaság bankunióhoz való csatlakozásáról (Impact study... [2015]). A szóba jöhető befolyásoló

${ }^{16}$ Reuters, 2014. július 14.

${ }^{17}$ FinancialObserver.eu, 2018. július 23.

${ }^{18}$ Az Eurócsoport az euróövezet pénzügyminisztereinek informális testülete.

${ }^{19}$ Reuters, 2018. november 12. 
tényezőket aszerint csoportosították, hogy azok vajon támogatják vagy ellenzik a korai bankunió-csatlakozást, esetleg semlegesek azzal kapcsolatban. A pénzügyi stabilitással jellemezhető időszakokra vonatkozóan egyedül az EKB felügyeleti tanácsában való részvételt és az ebből fakadó többletinformációkat találták a csatlakozás mellett szóló érvnek. Az ellenérvek közül a legfontosabbak: a felügyelet autonómiájának elvesztése, az engedélyezési jogkör elvesztése a cseh piacon működő intézmények esetében és a prudenciális követelmények (makro- és mikroprudenciális egyaránt) megállapítására vonatkozó kisebb lehetőség.

A pénzügyi stabilitás hiányával jellemezhető időszakokban egyáltalán nem találtak a csatlakozás mellett szóló érveket, viszont számos ellenérvet sorolnak fel. A legfontosabbak: megszűnik a hazai helyreállítási tervek előkészítésének és jóváhagyásának, valamint a saját értékelésen alapuló korai beavatkozásnak a joga, és megnő a felügyeleti szintű nemzetközi összefonódottságból fakadó fertőzési kockázat. A csatlakozás költségeivel kapcsolatban az EKB-nak fizetendő éves felügyeleti díj is az ellenérvek között szerepel. Végső következtetésként a hatástanulmány két ajánlást fogalmaz meg: 1. a jelenlegi feltételek mellett nem javasolja a bankunióhoz való csatlakozást; 2. a bankunió feltételeinek változása esetén 18 hónap múlva javasolja a hatásvizsgálat és az ezen alapuló cseh pozíció felülvizsgálatát. Jelenleg nem látható annak eredménye, hogy ez a felülvizsgálat megtörtént volna, és a cseh álláspontban bármilyen változás következett volna be. A Cseh Köztársaságnak nincs céldátuma az euróövezethez való csatlakozásra, és nincs olyan stratégiája, amely a közeli években való csatlakozás szándékát vetítené előre. Mindennek tükrében, jelenlegi tudásunk szerint igen valószínűtlen, hogy a Cseh Köztársaság a közeli jövőben csatlakozzon a bankunióhoz.

\section{Horvátország}

Legújabb tagállamaként Horvátország 2013-ban csatlakozott az EU-hoz. Bankrendszere a KKE6 országai közül a leginkább sérülékeny, akár a nemteljesítő hitelek arányát, akár a bankrendszeri Z-mutatót nézzük (4. és 5. ábra). A Világbanknak a kormányzás szintjére vonatkozó nemzetközi adatbázisa szerint a hat ország közül itt a leggyengébb a szabályozás minősége. Horvátország deklarálta, hogy csak a monetáris unióhoz való csatlakozással egyidejűleg fog belépni a bankunióba. Ennek okaként a központi bank elnöke azt jelölte meg, hogy a csatlakozás elött a jelenlegi körülmények között sokkal inkább képesek arra, hogy saját speciális érdekeiket megvédjék (Banking Union... [2016]).

Horvátországnak a bankunióba való belépéssel szembeni legfontosabb érvei között a döntéshozatal szintje (a bankunió szintje) és a döntés következményeinek és költségeinek viselése (nemzeti szint) közötti eltérés, a likviditási és költségvetési támogatásokhoz való hozzáférés hiánya, a bankunió felépítésének még hiányzó, ismeretlen elemei és általában is annak magas költségei szerepelnek. Ezen túlmenően attól is tartanak, hogy túl kicsik ahhoz, hogy az EKB kellő alapossággal felügyelje a horvát bankokat, és kellő figyelmet fordítson a horvát makroprudenciális kockázatok kialakulására. Pozitívumként azt emelik ki, hogy a bankokat tulajdonló anyabankokat is 
a bankunió felügyeli, és eddig kedvezők a tapasztalataik az egységes bankfelügyeleti rendszerrel való felügyeleti együttmüködéssel kapcsolatban (Šošić [2016]).

A horvát kormány 2018-ban elfogadta Horvátország euróövezeti csatlakozására vonatkozó stratégiáját. Ez nem határozott meg konkrét csatlakozási céldátumot, de leszögezte, hogy Horvátország érdeke, hogy olyan gyorsan csatlakozzon az euróövezethez, amilyen gyorsan csak lehetséges (Strategy for... [2018]). Ez azt is jelentheti, hogy Horvátországnak a bankunióhoz való csatlakozása nincs is olyan messze, mint azt az elözők alapján gondolhatjuk.

\section{Lengyelország - kivárás}

A lengyel bankrendszer, akárcsak a cseh, nem sérült súlyosan a válság alatt, a hitelezés nem esett vissza jelentősen a válság nyomán, nem halmozódott fel nagyarányú nemteljesítő hitelállomány, és folyamatosan sikerült fenntartani a bankrendszer jövedelmezőségét is (2., 3. és 4. ábra). A magyarhoz hasonlóan a lengyel bankpolitika is a banknacionalizmust követi (Mérö-Piroska [2016]), és támogatja a hazai tulajdon térnyerését a bankrendszerben. Ennek hatására a lengyel bankrendszer 2017-re vált többségében hazai tulajdonúvá. Kormányzási rendszere a cseh után a második legjobb a KKE6 országai között.

A lengyel központi bank elemezte azokat a közgazdasági kihívásokat, amelyek Lengyelországnak az euróövezethez való csatlakozásával kapcsolatban fennállnak (NBP [2015]), ennek részeként a bankunióhoz való csatlakozás mellett és ellene szóló érveket is áttekintette. Lengyel nézőpontból a bankunió gyengeségei a következők: nem egyenlő jogosítványok a döntéshozatalban, az ESM forrásaihoz való hozzáférés hiánya, a likviditási és tőkemenedzsmentre való kisebb ráhatás, a bankunió még alakulóban lévő felépítéséből fakadó bizonytalanságok. A lengyel jegybank elemzése azt is hangsúlyozta, hogy a makroprudenciális döntéshozatal rendszerében érdekütközés van az EKB és az Európai Rendszerkockázati Testület (European Systemic Risk Board, ESRB) között, hiszen mindkettőt az EKB elnöke vezeti. Így ha az ESRB rendszerkockázatot azonosít, akkor előfordulhat, hogy az EKB tevékenységével kapcsolatban kell figyelemfelhívást kiadnia. Vagyis lehetséges olyan helyzet, hogy az EKB elnöke a saját munkájával kapcsolatban kénytelen kiadni figyelemfelhívást. Kawalec [2015] három olyan tényezöt emel ki, amelyek különösen fontosak Lengyelország számára: 1. a lengyel bankrendszer kis mérete a lengyel gazdasághoz viszonyítva, ami egyben kisebb kockázatosságot is jelent, 2. az EKB által felügyelt anyabankok meghatározó helyzete a lengyel bankpiacon és 3 . a felügyelet szuverenitásának feladása az EKB és az ESM eszközeihez való hozzáférés nélkül.

Lengyelországnak sincs euróövezeti csatlakozási céldátuma, de a lengyel kormány nyilatkozataiban pozitívabb az euróövezeti csatlakozással kapcsolatban, mint a cseh és a magyar. ${ }^{20} \mathrm{~A}$ lengyel pénzügyminiszter-helyettes 2016 októberében azt nyilatkozta

${ }^{20}$ Az Európai Bizottság hivatalos honlapján, az EU Countries and the euro című oldalán az található, hogy bár Lengyelországnak nincs euróövezeti csatlakozási céldátuma, de célkitűzés a lehető leg- 
azonban, hogy még ha minden a legjobban menne is, Lengyelország akkor is legkorábban 5-10 év múlva csatlakozhat az euróövezethez (Polanski [2017]), ami azt jelenti, hogy jó eséllyel Lengyelország sem fog a következő években csatlakozni a bankunióhoz.

\section{Magyarország - kivárás}

A magyar bankrendszert nagyon komolyan érintette a válság. A válság előtt a magyar bankrendszer volt leginkább kitéve a külföldi forrásoknak (1. ábra), és a válságot követően itt esett vissza legeröteljesebben a hitelezés (2. ábra). Emellett a KKE6 országai között a magyar bankrendszer a leginkább koncentrált. A válságot követő fellendülés csak 2015-re bontakozott ki, azóta mind a nemteljesítő hitelek aránya, mind a Z-mutató a KKE6 átlagértékei körül van (4. és 5. ábra). A válságot követően a kiemelkedően magas bankrendszeri veszteségek nemcsak a bankok rossz teljesítményét tükrözik, hanem a magas banki különadókat is (3. ábra). A magyar kormány banknacionalista bankpolitikájával összhangban (Mérö-Piroska [2017a]) a külföldi banktulajdon részaránya 2013 után számottevően kezdett csökkenni, 2015-re a magyar bankszektorban többségivé vált a hazai tulajdon. A Világbanknak a kormányzás szintjére vonatkozó nemzetközi adatbázisa szerint a szabályozás minősége és a korrupció kontrollja is jelentősen, míg a jogállamiság és a kormányzat hatásossága valamelyest romlott Magyarországon a 2010-es években. Ennek a folyamatnak a következtében a magyar kormányzásra vonatkozó mutatók értéke 2016-ra jelentősen leszakadt a megfelelő cseh és lengyel értékektől. 2016-ra a szabályozás általános minőségére vonatkozó mutató rosszabb lett, mint a bolgár érték, míg a korrupció kontrolljára vonatkozó mutató a horvát értéknél lett rosszabb.

A Magyar Nemzeti Bank átfogó elemzést végzett a bankunióhoz való csatlakozás mellett és ellen szóló érvekről (Kisgergely-Szombati [2014]). Az elemzés a bankunió általános irányítási rendszere, a mikroprudenciális felügyelet, a makroprudenciális politika, a válságkezelés és a monetáris politikai hatások szemszögéből tekinti át a kérdéskört. Pozitívumként a harmonizált európai rendszerhez való csatlakozást, az EKB magas reputációját és a nagy összegü SRF elérhetőségét emeli ki. A negatív oldalon az érvek két típusa különböztethető meg. Egyrészt a nem sokkal korábban átalakított hazai felügyeleti rendszer jó minőségét és a pénzügyi stabilitás megőrzésére való képességét emelik ki a szerzők, másrészt a bankunió jelenlegi hiányosságaira helyezik a súlyt. Ez utóbbiak között kiemelik a hazai felügyeleti hatóságok és az EKB közötti munkamegosztás tisztázatlan kérdéseit, a bankunió döntéshozatalában való részvétel korlátozott jogosítványait (mind a mikro-, mind a makroprudenciális ügyekben), a még tisztázatlan, lassú és bürokratikus válságkezelési mechanizmust, az egységes betétbiztosítási rendszert. Továbbá a költségvetési támogatás kérdését, ami még a monetáris unió szintjén sincs megoldva, illetve az EKB likviditási

hamarabb történő csatlakozás. Ezzel szemben ugyanezen a honlapon a magyar és a cseh euróövezeti csatlakozással kapcsolatban csak annyi szerepel, hogy nincs céldátum az euró bevezetésére (https:// ec.europa.eu/info/business-economy-euro/euro-area/euro/eu-countries-and-euro_hu). 
eszközeihez és az ESM-támogatáshoz való hozzáférés hiányát az önként csatlakozó országok esetében. Az MNB-tanulmány végkövetkeztetése az, hogy a magyar kormány legjobb döntése ebben a helyzetben a kivárás. Az anyag 2014-es megjelenése óta a magyar pozíció újabb felülvizsgálata a makroprudenciális szabályozási politikára és gyakorlatra vonatkozott: Szombati [2017] hangsúlyozza, hogy a hazai esetben egyértelmübb a feladat- és a felelősségi körök elhatárolása, és maga a hazai makroprudenciális szabályozás is jobban működik, mint az EKB keretében végzett. Vagyis ez is a kivárás álláspontját erősítette meg. A Cseh Köztársasághoz hasonlóan Magyarországnak sincs jelenleg euróövezeti csatlakozási céldátuma, sőt a magyar pénzügyminiszter, Varga Mihály azt nyilatkozta, hogy Magyarország nem siet csatlakozni az euróövezethez. ${ }^{21}$ Vagyis Magyarország esetében szintén nem várható, hogy a közeljövőben csatlakozik a bankunióhoz.

\section{Románia - csatlakozás}

Románia bankrendszere a legfejletlenebb, ha a fejlettséget a pénzügyi közvetítés mélységével mérjük (2. ábra), és Magyarország mellett a román hitelezés visszaesése volt a legerősebb a válság éveiben. A válság nyomán itt halmozódott fel a legnagyobb arányú nemteljesítő hitelállomány (4. ábra), azonban a megfelelő felügyeleti beavatkozások hatására sikerült számottevően mérsékelni (IMF [2018]). 2016 végére már mind a bolgár, mind a horvát bankrendszer nemteljesítő hitelállománya nagyobb volt, mint a román bankrendszeré. A román bankrendszer jövedelmezősége a válság elött a régió legjobbjai között volt, majd a válság alatt - a magyarral együtt a legrosszabb lett, ami azt jelenti, hogy a bankszektor több egymást követő évben is veszteségesen működött (3. ábra). Románia kormányzásának színvonala a KKE6 országainak az alsó szegmensében található, a kormányzati hatásossága a leggyengébb, míg a szabályozás minősége, a korrupció kontrollja és a jogállamiság a második leggyengébb az országcsoporton belül.

Bulgáriával együtt Románia is elkötelezett a bankunióhoz való csatlakozás mellett, bár még nem küldte meg az erre vonatkozó kérelmét az EKB-nak. Romániának 2024 az euróövezeti csatlakozásra vonatkozó céldátuma. ${ }^{22}$ Hivatalos nyilatkozataiban a kezdetektől (eleinte egyedüli tagállamként) Románia azt hangsúlyozta, hogy az ország számára fontos a bankunióhoz való csatlakozás. A központi bank kormányzója öt fó érvet hozott fel amellett, hogy miért fontos Románia számára a csatlakozás (Isarescu [2014]). Ezek: az EU-szintű információkhoz való jobb hozzáférés, a bankszektor erősebb európai integrációja a bankunió által felügyelt anyabankok meghatározó szerepe miatt, a hitelezés visszaszorulásához kapcsolódó ösztönzők megszűnése, versengőbb piac kialakulása és a leányvállalatok fiókká alakulására irányuló ösztönzők megszünése, a csatlakozás elmaradásának magas költségei. Isarescu

\footnotetext{
${ }^{21}$ Reuters, 2018. március 24.

${ }^{22}$ Romania and the euro (https://ec.europa.eu/info/business-economy-euro/euro-area/euro/eucountries-and-euro/romania-and-euro_en).
} 
[2014] is tisztában van azzal, hogy a nem euróövezeti tagállamok nem kapnak egyenlő jogokat a bankunión belül, és nem férhetnek hozzá a likviditási és költségvetési támogatásokhoz, de ezeket nem tekinti a gyors csatlakozást kizáró okoknak, hanem az újratárgyalás szükségességét hangsúlyozza. Annak tükrében, hogy az EU milyen választ adott a bolgár csatlakozási kérelemre, vélelmezhető, hogy a román kérelemre is hasonló előzetes feltételek kiszabása lenne a válasz.

\section{Következtetések}

Az Európai Unió lehetővé tette, hogy a nem euróövezeti tagállamok már az euróövezethez való csatlakozás előtt - úgynevezett szoros együttmüködés formájában belépjenek a bankunióba. Ez azonban számos megkülönböztetést tartalmaz az így csatlakozókra vonatkozóan. Ez az EU kettősségét mutatja a belépéssel kapcsolatban: megengedi, de nem bátorítja. Miközben az erősebb pénzügyi integráció az egész EU érdekét szolgálná, ha minden megszorítás nélkül engednék be a nem euróövezeti tagállamokat a bankunióba, az azt is jelentené, hogy ezek a tagállamok úgy férnének hozzá az EU likviditási és költségvetési támaszaihoz, hogy közben az EKB-nak nincs ráhatása ezen országok monetáris politikájára. A legfontosabb megszorítások a nem euróövezeti tagállamok csatlakozásával kapcsolatban az EKB kormányzótanácsában való képviselet hiánya, illetve a költségvetési és likviditási eszközökhöz való hozzáférés hiánya. A korlátozások ellenére a bankunióhoz való csatlakozás jelentősen növelheti az érintett országok bankfelügyeletének színvonalát és hitelességét, továbbá javíthatja az európai banki ügyekre való rálátásukat, és nagyobb beleszólást enged a bankunió jövőjének formálásába. Ennek az ellentmondásos helyzetnek a következménye az, hogy mind a szakirodalom, mind az egyes KKE6-országok véleménye igen megosztott a témával kapcsolatban.

Áttekintve a KKE6-országok bankrendszereinek sajátosságait és a bankunióhoz való csatlakozásukkal kapcsolatos pozíciójukat, nehéz meghatározni az azonosságokat és a különbözöséget a csatlakozni szándékozó és a kiváró országok között. Elemzésünk leginkább Mérö-Piroska [2016] érvelését támasztja alá, amely szerint Bulgáriát és Romániát az államkapacitás alacsony szintje és a pénzügyi stabilitási problémák ösztönözhetik inkább a csatlakozásra, míg a többi ország banknacionalizmusa hathat a kivárás melletti döntésre.

A helyzet leginkább a 22-es csapdájára emlékeztet: ha az EU teljesen egyenlő jogokat adna a bankunióhoz csatlakozó nem euróövezeti országok számára, akkor ez további érvként szolgálhatna a számukra az euró bevezetése - és így a mélyebb integráció - ellen. Másik oldalról viszont, ha nem ad több tekintetben egyenlö jogokat, akkor a kompetenciák és felelősségek közötti összhanghiány a bankunióba való belépés - és ezzel együtt az EU-szintủ pénzügyi integráció mélyülése - ellen ösztönöz. Erre a csapdahelyzetre reflektálva, a makroprudenciális felhatalmazások bankunión belüli és kívüli jogosítványainak kérdésére összpontosítva fogalmaz meg MéröPiroska [2018] számos olyan reformjavaslatot, amelyek a csatlakozó országok esetében javíthatják a kompetenciák és felelősségek közötti összhangot. 
A bankuniót mindenképpen szükséges lenne megreformálni annak érdekében, hogy vonzóbb legyen a nem euróövezeti országok számára, és így segítse az integráció mélyülését. Ugyanakkor valamekkora különbségtételt indokol az, hogy csak így tartható fenn a bankunióba való belépést követően is az euróövezeti csatlakozásra való ösztönzöttség. Összességében tehát a jelenlegi feltételek mellett nincs egységes, kizárólagos jó válasz a csatlakozás vagy a kívül maradás dilemmájára, mind a hat keletközép-európai ország az érvek és ellenérvek saját szempontjából való mérlegelése alapján dönt a kérdésről. Nemcsak a geometriához, a bankunióhoz sem vezet királyi út.

\section{Hivatkozások}

BANKING UNION... [2016]: Banking Union - the state of play and challenges ahead. Hrvatska Narodna Banka, https://www.hnb.hr/en/-/bankovna-unija-ostvarenja-i-izazovi.

BeCK, T. [2012]: Why the rush? Short-term crisis resolution and long-term bank stability. Megjelent: Beck, T. (szerk.): Banking Union for Europe - Risks and Challenges. Centre for Economic Policy Research (CEPR). A VoxEu.org Book. https://voxeu.org/article/why-rushshort-term-crisis-resolution-and-long-term-bank-stability.

Belke, A.-Dobrzanska, A.-Gros, D.-Smaga, P. [2016]: (When) should a non-euro country join the banking union? The Journal of Economic Asymmetries, Vol. 14. Part A. 4-19. o. https://doi.org/10.1016/j.jeca.2016.07.008.

BenediktsdótTiR, S. [2014]: European Banking Union: Will Outsiders Be Affected? Megjelent: Toward a European Banking Union: Taking Stock. $42^{\text {nd }}$ Economics Conference of Oesterreichische Nationalbank. 67-77. o. https://www.oenb.at/en/Publications/Economics/ Economics-Conference/2014/Economics-Conference-2014.html.

Bluedorn, J.-Ilyina, A.-Iossiof, P.[2015a]: Opting into the banking union before euro adoption Megjelent: Toward a Genuine Economic and Monetary Union. Proceedings of OeNB Workshops, szeptember 10-11. https://www.oenb.at/dam/jcr:5e51412f-d64e-42d9a579-e45033151f1c/watt_quantitative\%20easing\%20with\%20bite_paper.pdf.

Bluedorn, J.-Ilyina, A.-Iossiof, P. [2015b]: Banking Union Before Euro Adoption: Flak Jacket or Straitjacket? IMF blog, augusztus 19. https://blogs.imf.org/2015/08/19/bankingunion-before-euro-adoption-flak-jacket-or-straitjacket.

Сinák, M.-Demirgüc-Kunt, A.-Feyen, E.-Levine, R. [2012]: Benchmarking financial system around the world. The World Bank Policy Research Working Papers, No. 6175. https:// doi.org/10.1596/1813-9450-6175.

Constancio, V. [2013]: Implications of SSM on the ESFS. Public Hearing on Financial Supervision in the EU. Brüsszel, május 24. https://www.ecb.europa.eu/press/key/date/2013/html/ sp130524.en.html.

Darvas Zsolt-WolfF, G. B. [2013]: Should non-euro are countries join the single supervisory mechanism? Bruegel Policy Contribution, No. 6. http://bruegel.org/2013/03/shouldnon-euro-area-countries-join-the-single-supervisory-mechanism.

De HaAs, R.-Kornyienko, Y.-Loukpianova, E.-Pivovarsky, A. [2012]: Foreign Banks and the Vienna Initiative: Turning Sinners into Saints. IMF Working Papers, Vol. 12. No. 117. https://doi.org/10.5089/9781475503463.001.

EB [2012]: Az Európai Bizottság közleménye az Európai Parlamentnek és a Tanácsnak egy bankunió kiépitését eredményező ütemtervről. COM (2012) 510 final, Európai Bizottság, 
Brüsszel, szeptember 12. https://eur-lex.europa.eu/LexUriServ/LexUriServ.do?uri=COM: 2012:0510:FIN:HU:PDF.

EB [2018]: Módosítási javaslat a pénzügyi rendszerek pénzmosás vagy terrorizmusfinanszírozás céljára való felhasználásának megelőzéséről szóló [EU] 2015/849. sz. irányelv módosításáról. COM (2018) 646 final, 2017/0230 (COD). Európai Bizottság, Brüsszel, szeptember 12. https:// eur-lex.europa.eu/legal-content/HU/TXT/PDF/?uri=CELEX:52018PC0646\&from=HU.

ECB [2017]: Report on Financial Structures. Október. https://www.ecb.europa.eu/pub/pdf/ other/reportonfinancialstructures201710.en.pdf.

Epstein, R. [2013]: When do foreign banks 'cut and run'? Evidence from west European bailouts and east European markets. Review of International Political Economy, Vol. 21. No. 4. 847-877. o. https://doi.org/10.1080/09692290.2013.824913.

EU [2013]: A Tanács 1024/2013/EU rendelete az Európai Központi Banknak a hitelintézetek prudenciális felügyeletére vonatkozó politikákkal kapcsolatos külön feladatokkal történő megbízásáról (2013. október 15.). HL. L 287. október 29. https://eur-lex.europa.eu/legalcontent/HU/TXT/PDF/?uri=CELEX:32013R1024\&from=HU.

EU [2018]: Press Release 12/07/2018 Statement on Bulgaria's path towards ERM II participation. https://www.consilium.europa.eu/hu/press/press-releases/2018/07/12/statementon-bulgaria-s-path-towards-erm-ii-participation.

Howarth, D.-Quaglia, L. [2013]: Banking Union as Holy Grail: Rebuilding the Single Market in Financial Services, Stabilizing Europe's Banks and 'Completing' Economic and Monetary Union. Journal of Common Market Studies, Vol. 51. 103-123. o. https://doi. org/10.1111/jcms.1205423.

Howarth, D.-Quaglia, L. [2016]: The Political Economy of European Banking Union. Oxford University Press, https://doi.org/10.1093/acprof:oso/9780198727927.003.0005.

Hüttr, P.-Schoenmaker, D. [2016]: Should the 'outs' join the European Banking Union? Policy Contribution. Bruegel Policy Contribution, No. 3. http://bruegel.org/wp-content/ uploads/2016/02/pc_2016_03.pdf.

IMF [2015]: Central and Eastern Europe: New Members States (NMS) Policy Forum, 2014. IMF Country Report, No. 97.

IMF [2018]: Romania - Financial Sector Assessment Program. IMF Country Report, No. 160. IMPACT STUDY... [2015]: Impact study on participation or non-participation of Czech Republic in the Banking Union. Summary report Ministry of Finance of the Czech Republic in cooperation with the Ministry of Foreign Affairs of the Czech Republic. The Office of the Government of Czech Republic and the Czech National Bank, február 9.

IsARESCU, M. [2014]: Relations between euro and non-euro countries within the Banking Union. Speech before the UniCredit $15^{\text {th }}$ International Advisory Board, Róma, július 10 .

Johnson, J.-BARnes, A. [2015]: Financial Nationalism and its International Enablers: The Hungarian Experience. Review of International Political Economy, Vol. 22. No. 3. 535-569. o. https://doi.org/10.1080/09692290.2014.919336.

Kawalec, S. [2015]: Poland and the Dilemmas of the Banking Union. Megjelent: Reich, A.Kawalec, S.: The Banking Union: state of art. CASE Seminar Proceedings, No. 137.

Kisgergely KornéL-Szombati Anikó [2014]: Bankunió magyar szemmel - hogyan látja az MNB a szoros együttműködés lehetőségét? MNB-tanulmányok 115. https://www.mnb. hu/letoltes/mt115-mnb-tanulmany.pdf.

MÉrő Katalin-Piroska Dóra [2016]: Banking Union and banking nationalism. Explaining opt-out choices of Hungary, Poland and the Czech Republic. Policy and Society, Vol. 35. No. 3. 215-226. o. https://doi.org/10.1016/j.polsoc.2016.10.001. 
Mérő Katalin-Piroska Dóra [2017a]: Bankunió és banknacionalizmus. A magyar eset keletközép-európai kontextusban. Politikatudományi Szemle, 26. évf. 1. sz. 135-160. o.

Mérő Katalin-Piroska DóRa [2017b]: Az Európai Bankunió reformja. A makroprudenciális felhatalmazások rendszerének újragondolása a kelet- és közép-európai országok szemszögéből. Külgazdaság, 61. évf. 9-10. sz. 3-29. o.

MÉRő KATALIN-Piroska Dóra [2018]: Rethinking the allocation of macroprudential mandates within the Banking Union. A perspective from east of the BU. Journal of Economic Policy Reform, Vol. 21. No. 3. 240-256. o. https://doi.org/10.1080/17487870.2017.1400435.

Moloney, N. [2014]: European Banking Union: assessing its risks and Resilience. Common Market Law Review, Vol. 51. No. 6. 1609-1670. o.

Montanaro, E. [2016]: The Process towards Centralisation of the European Financial Supervisory Architecture: the Case of the Banking Union. PSL Quarterly Review, Vol. 69. No. 277. 135-172. o. https://ojs.uniroma1.it/index.php/PSLQuarterlyReview/article/view/13696.

NBP [2015]: The economic challenges of Poland's integration with the euro area. Narodowy Bank Polsky, Varsó, március, https://www.nbp.pl/en/publikacje/inne/The-economicchallenges-of-Poland-s-integration-with-the-euro-area.pdf.

Polanski, Z. [2017]: Poland and the European Banking Union: First experiences. Január 9. http://www.europolis-online.org/wp-content/uploads/2017/01/Polanski.pdf.

Schimmelfenning, F. [2016]: A Differentiated Leap Forward: Spillover, Path-dependency, and Graded Membership in European Banking Regulation. West European Politics, Vol. 39. No. 3. 483-502. o. https://doi.org/10.1080/01402382.2016.1143244.

Šošıć, V. [2016]: Bankova unija iz perspective drzave clanice izvan europodrucja. Presentation on the conference Banking Union. The State of Play and Challanges Ahed, május 18. https://www.hnb.hr/en/-/bankovna-unija-ostvarenja-i-izazovi.

Spendzharova, A. [2014]: Banking union under construction: The impact of foreign ownership and domestic banking internationalization on European Union member states' regulatory preferences in banking supervision. Review of International Political Economy, Vol. 21. No. 4. 949-979. o. https://doi.org/10.1080/09692290.2013.828648.

STRATEGY FOR... [2018]: Strategy for the adoption of the euro in the Republic of Croatia. Government of the Republic of Croatia and Croatian National Bank, április, https:/euro. hnb.hr/documents/2070751/2104255/e-strategy-for-the-adoption-of-the-euroin-Cro. pdf/9e02b33f-665a-46a9-a1b6-ac63f9af3c95.

Szombati Anikó [2017]: Merre tovább? A rendszerkockázat-kezelés kereteinek fejlesztése az EU-ban. MNB, Budapest, http://www.mnb.hu/kiadvanyok/szakmai-cikkek/ a-bankrendszer-jovoje/szombati-aniko-merre-tovabb-a-rendszerkockazat-kezeleskereteinek-fejlesztese-az-eu-ban.

Vienna Initiative [2018]: Report by the Working Group on Capital Markets Union, Endorsed by the Vienna Initiative Full Forum Meeting, március 12. http://vienna-initiative.com/ resources/themes/vienna/wp-content/uploads/2018/03/VI-CMU-Working-Group-FinalReport-March-2018.pdf.

Vollmer, U. [2016]: The Asymmetric Implementation of the European Banking Union [EBU]: Consequences for Financial Stability. International Journal of Management and Economics, Vol. 50. No. 1. 7-26. o. https://doi.org/10.1515/ijme-2016-0009. 